\title{
Products Liability and "Off-Label" Uses of Prescription Drugs
}

\author{
Kaspar J. Stoffelmayr†
}

In order to win approval for a new prescription drug from the Food and Drug Administration ("FDA"), the drug's manufacturer must demonstrate that it is both safe and effective. ${ }^{1}$ The FDA then approves the drug for the uses for which it has been shown to be effective. ${ }^{2}$ The drug's manufacturer may not promote the drug or give prescribing information for any other, unapproved uses. ${ }^{3}$

Physicians, however, routinely prescribe drugs for "off-label" uses. An off-label use is one other than the FDA-approved uses described on a drug's official labeling. ${ }^{4}$ There is nothing unethical or even unusual about off-label prescriptions, and it is likely that close to one-half of all American drug prescriptions are for off-label uses. ${ }^{5}$

Off-label uses of prescription drugs have important benefits. They constitute the best treatment for many patients, and they may also be a valuable source of medical innovation. ${ }^{6}$ Inevitably, however, off-label drug uses also create special risks that are not present when drugs are used in manners that the FDA has approved.

This Comment examines the liability of drug manufacturers for injuries stemming from off-label uses of prescription drugs. As off-label drug uses have become more common, associated prod-

† B.A. 1991, Grinnell College; M.A. 1993, University of Washington; J.D. Candidate 1996, The University of Chicago.

1 Federal Food, Drug, and Cosmetic Act, 21 USC § 355 (1988 \& Supp 1994); FDA, Applications for FDA Approval to Market a New Drug or an Antibiotic Drug, 21 CFR \$§ 314.50, 314.100-314.170 (1995). For a description of the FDA approval process, see generally David A. Kessler, The Regulation of Investigational Drugs, 320 New Eng J Med 281 (1989).

221 USC $\S 355(d)(1988) ; 21$ CFR $\$ 314.110$.

321 USC $\$ 355(d) ; 21$ CFR \$ 314.125(a)-(b).

4 "Labeling" is defined broadly in this context and includes "all labels and other written, printed, or graphic matter (1) upon any article or any of its containers or wrappers, or (2) accompanying such article." 21 USC § 321(m) (1988 \& Supp 1994).

- See text accompanying notes 19-22.

- See text accompanying notes 15-18, 23-24. 
ucts liability litigation has increased, resulting in a small but growing body of inconsistent case law in which courts have adopted a wide variety of rules about drug manufacturers' duties regarding off-label drug uses. ${ }^{7}$ Section I of this Comment describes off-label uses of prescription drugs more specifically, and Section II outlines the general rules governing drug products liability. Section III then examines the various positions courts have taken on manufacturer liability for injuries caused by offlabel drug uses. It argues that even the most promising approaches fail to reconcile adequately the competing goals of assuring that manufacturers have sufficient incentives to warn of risks and of devising a liability scheme that does not impose excessive costs on manufacturers. Finally, Section IV proposes a solution to this problem, arguing that a drug manufacturer's duty should be to warn of all demonstrated risks associated with an off-label drug use, whether they are demonstrated by the manufacturer's own research, the research of others, or physicians' experiences using the drug.

\section{Off-Label Uses of PRescription DRUgS}

As part of its application for approval of a new prescription drug, a drug manufacturer must submit proposed labeling to the FDA. $^{8}$ This labeling must include a proposed package insert to be included with the drug and reprinted in the Physicians' Desk Reference, the standard reference work to which physicians turn when prescribing drugs. The package insert must include information about when to prescribe the drug, how to administer it, risks associated with it, and circumstances under which it should not be used. ${ }^{9}$ The FDA will approve a new drug application only if it finds the proposed labeling acceptable. In particular, it will not approve an application if the labeling instructs physicians in uses other than those for which the drug has been shown to be safe and effective. ${ }^{10}$

7 In the words of one commentator, products liability decisions concerning off-label drug uses "are most notable for their complete lack of consistency with one another." Lars Noah, Constraints on the Off-Label Uses of Prescription Drug Products, $16 \mathrm{~J}$ Prod \& Toxics Liab 139, 160 (1994).

\& See 21 USC § 355(b)(1)(F) (1988); 21 CFR § 314.50(e)(2)(ii).

9 See FDA, Labeling, 21 CFR $\S \S 201.56-201.57,201.100$ (1995).

10 21 USC § 355(d); 21 CFR § 314.125(a)-(b). As an alternative to rejecting the application, the FDA may make its approval conditional on changes in the proposed labeling. 21 CFR § 314.110(a). 
As new uses for a prescription drug become known, the manufacturer may seek to have them approved, and, if successful, can add the new uses to the drug's labeling. ${ }^{11}$ However, since the FDA approval process for a new use of a drug already on the market is extremely expensive and can take several years, drug manufacturers often prefer to leave off-label drug uses unapproved. ${ }^{12}$ If an off-label use is already well known among physicians, adding it to the label would likely have little effect on sales. Additionally, since less than the full life of a drug's patent usually remains when off-label uses become known, it is harder for a drug manufacturer to recover its investment in having an off-label use approved than it is to recover the initial investment in having the drug approved for its original use. ${ }^{13}$

Physicians, however, are free to prescribe drugs for any uses they believe are appropriate. There are a number of ways in which the use of a prescription drug can diverge from the FDAapproved uses described on its labeling. ${ }^{14}$ For example, physicians may prescribe a drug to treat conditions other than those for which the drug was originally intended. Physicians may also prescribe a drug for patient groups other than those for whom the drug was originally approved, as when children are prescribed a drug approved for use on adults only. Finally, physicians may vary the dosage or method of administering a drug, as when a drug approved for injection into muscles only is injected into a vein.

Under the right circumstances, any one of these types of offlabel drug uses might be an appropriate way to treat a patient. Many off-label uses of prescription drugs are widely known and well understood; such uses are accordingly recommended by med-

1 See 21 CFR $\S \S 314.54,314.70-314.71$ (1995). The procedure for such an application is essentially the same as the procedure for an initial new drug application. 21 CFR $\S \S$ 314.54, 314.70. A manufacturer may not otherwise make any significant changes in a drug's labeling without FDA approval. $21 \mathrm{CFR} \$ 314.70$ (b)(3).

${ }_{12}$ J. Howard Beales, III, Economic Analysis and the Regulation of Pharmaceutical Advertising, 24 Seton Hall L Rev 1370, 1387, $1392-93$ (1994); Paul H. Rubin, From Bad to Worse: Recent FDA Initiatives and Consumer Health, in Richard T. Kaplar, ed, Bad Prescription for the First Amendment: FDA Censorship of Drug Advertising and Promotion 87, 92 (Media Institute 1993).

${ }^{13}$ Rubin, From Bad to Worse at 92 (cited in note 12). One commentator has also suggested that manufacturers face ethical problems when using placebo control groups to study drug uses that are known to be effective. Noah, $16 \mathrm{~J}$ Prod \& Toxics Liab at 145 (cited in note 7).

14 William L. Christopher, Off-Label Drug Prescription: Filling the Regulatory Vacuum, 48 Food \& Drug L J 247, 248 (1993), catalogs various types of off-label uses of prescription drugs. 
ical textbooks, ${ }^{15}$ research institutes, ${ }^{16}$ and professional organizations, ${ }^{17}$ as well as described in standard pharmaceutical reference works. ${ }^{18}$

Since unapproved drug uses are sometimes the best therapy available for patients, and since drug manufacturers often lack incentives to seek FDA approval for them, off-label uses of prescription drugs have become very common. A General Accounting Office study found that about one-third of all drug treatment for cancer involved off-label drug uses. ${ }^{19}$ The study also found that over half of the cancer patients surveyed had received at least one off-label prescription, all major types of cancer studied had been treated through off-label drug uses, and off-label uses accounted for 85 percent of the prescriptions of three popular cancer drugs. ${ }^{20}$ Less information is available in other areas, but there is general agreement that at least one-quarter of all U.S. prescriptions are for off-label drug uses, ${ }^{21}$ and the American Medical Association's Vice President of Science and Education has estimated this figure to be between 40 and 60 percent. ${ }^{22}$

Clearly, off-label drug use has become an important part of mainstream, legitimate medical practice. According to an officer of the American Medical Association, "[i]n some cases, if you didn't use the drug in the off-label way you'd be guilty of mal-

15 See Proctor $v$ Davis, $1994 \mathrm{Ml}$ App LEXIS 995, *6 (indicating that medical textbooks recommended off-label use of Depo-Medrol).

${ }^{16}$ See, for example, Robert F. Ozols, Letter, 326 New Eng J Med 134, 134 (1992) (indicating that the National Cancer Institute frequently recommends off-label use of drugs).

${ }_{17}$ See, for example, id (indicating that the Gynecologic Oncology Group accepts offlabel use of drugs as standard treatment).

${ }^{18}$ See Drusilla S. Raiford, Sheila R. Shulman, and Louis Lasagna, Determining Appropriate Reimbursement for Prescription Drugs: Off Label Uses and Investigational Therapies, 49 Food \& Drug L J 37, 40 (1994).

${ }_{19}$ United States General Accounting Office, Pub No GAO/PEMD-91-14, Off-Label Drugs: Reimbursement Policies Constrain Physicians in Their Choice of Cancer Therapies 19 (1991).

${ }^{20}$ Id at 21, 22, 25.

${ }^{21}$ See, for example, Noah, $16 \mathrm{~J}$ Prod \& Toxics Liab at 139 (cited in note 7); Beales, 24 Seton Hall L Rev at 1386 (cited in note 12); Rubin, From Bad to Worse at 91 (cited in note 12); Stephen Chapman, FDA censorship is a real danger to your health, Chi Trib Section 1 at 25 (Apr 15, 1993); Andrew Purvis, The FDA's Next Target: Drugs, Time 56 (July 15, 1991).

22 See Fran Kritz, FDA Seeks to Add Drugs' New Uses to Labels, Wash Post Health 11 (Mar 29, 1994). See also Stephen Chapman, The FDA and other enemies of public health, Chi Trib Section 4 at 3 (Feb 26, 1995) ("About half of all drug therapy today-and at least 60 percent of drug therapy for cancer-involves the use of approved drugs for unapproved, 'off-label' purposes."). 
practice.."23 In addition to being the best treatment for many patients, off-label drug use may also be an important means of discovering effective new therapies. ${ }^{24}$

The FDA has long tolerated off-label drug use and has disclaimed any interest in regulating physicians' prescribing practices. ${ }^{25}$ Indeed, it is unclear whether the agency even has jurisdiction to regulate the prescription of drugs for off-label uses, although the agency maintains that it does. ${ }^{26}$

The FDA does, however, actively control manufacturers' communications with physicians and the public about off-label drug uses. As noted above, official drug labeling cannot contain instructions for off-label uses, ${ }^{27}$ and FDA regulations also prohibit drug manufacturers from advertising or otherwise promoting unapproved uses of their drugs. ${ }^{28}$

Manufacturers obviously have a significant financial interest in encouraging off-label uses of their drugs, since these uses increase their overall sales. As a result, despite the FDA restrictions, manufacturers have been very successful at promoting off-

${ }^{23}$ See Kritz, FDA Seeks to Add Drugs' New Uses, Wash Post Health at 11 (cited in note 22 ).

${ }^{24}$ See Christopher, 48 Food \& Drug L J at 249 (cited in note 14) (“[A]necdotal evidence from general medicine suggests that off-label use frequently leads to serendipitous drug discovery."); Sydney A. Shapiro, Limiting Physician Freedom to Prescribe a Drug for Any Purpose: The Need for FDA Regulation, 73 Nw U L Rev 801, 809 (1978) (noting that effective off-label drug uses may be discovered when physicians try therapies based on informal theorizing, or when a patient with multiple conditions receives a drug to treat one condition and another condition unexpectedly improves as well).

25 See FDA, Proposed New Drug, Antibiotic, and Biologic Drug Product Regulations, 48 Fed Reg 26720, 26733 (1983); FDA, Legal Status of Approved Labeling for Prescription Drugs; Prescribing for Uses Unapproved by the Food and Drug Administration, 37 Fed Reg 16503, 16503 (1972); Use of Approved Drugs for Unlabeled Indications, 12 FDA Drug Bull 4, 5 (Apr 1982).

${ }^{26}$ See Kritz, FDA Seeks to Add Drugs' New Uses, Wash Post Health at 11 (cited in note 22). See also David A. Kessler, Regulating the Prescribing of Human Drugs for Nonapproved Uses Under the Food, Drug, and Cosmetic Act, 15 Harv J Leg 693, 714-19 (1978) (future FDA Commissioner Kessler arguing that the FDA has jurisdiction to regulate off-label drug use).

27 See text accompanying note 10 .

2* FDA, Prescription Drug Advertising, 21 CFR $\$ 202.1(e)(4)$ (1995). Although the regulations explicitly restrict only "advertisements," the FDA takes the position that they apply to all promotional activity. See David G. Adams, FDA Regulation of Communications on Pharmaceutical Products, 24 Seton Hall L Rev 1399, 1407-08 (1994); David A. Kessler and Wayne L. Pines, The Federal Regulation of Prescription Drug Advertising and Promotion, 264 JAMA 2409, 2409-10 (1990). Commentators have heavily criticized the FDA for these regulations. See Beales, 24 Seton Hall $L$ Rev at 1370 (cited in note 12); Richard A. Samp, What the FDA Doesn't Want You to Know Could Kill You, 9 Legal Backgrounder 1 (Oct 7, 1994); Rubin, From Bad to Worse at 92 (cited in note 12); Chapman, FDA censorship, Chi Trib Section 1 at 25 (cited in note 21). 
label uses. ${ }^{29}$ Among the most common methods are funding research into off-label drug uses, sponsoring continuing education programs and symposia in which ostensibly independent researchers discuss off-label uses, distributing reprints of journal articles on off-label uses, and purchasing special journal supplements that feature articles about off-label uses. ${ }^{30}$ The FDA permits these and other such activities, provided that drug manufacturers follow rules designed to ensure that the research remains objective. ${ }^{31}$ Manufacturers may also provide any information regarding off-label uses of their drugs that physicians specifically request. ${ }^{32}$ Less ethical efforts by manufacturers to promote offlabel drug uses include, for example, paying physicians to participate in sham "seeding trials," in which physicians prescribe offlabel drug therapies as part of supposed scientific studies that in reality serve only to introduce participating physicians and their colleagues to the off-label uses. ${ }^{33}$

Because drug manufacturers generally do not perform the safety and efficacy studies required by the FDA approval process for off-label drug uses, and because manufacturers cannot provide physicians with prescribing information for such uses, offlabel uses of prescription drugs can be risky, and some off-label uses have turned out to be very dangerous. ${ }^{34}$ As a result, a num-

29 For instance, Robert S. Stern, Drug Promotion for an Unlabeled Indication: The Case of Topical Tretinoin, 331 New Eng J Med 1348 (1994), documents how the manufacturer of Retin-A, an acne medication, engineered a dramatic increase in the number of prescriptions for the drug by publicizing, in both the popular and the scientific press, the drug's off-label use as an antiwrinkle cream. In an unusual turn of events, Retin-A's manufacturer has since pled guilty to obstruction of justice, admitting that it destroyed records after the Justice Department began a criminal investigation into its promotional activities. See William M. Carley, Court Papers Detail Ortho's Retin-A Deception, Wall St J B1 (Mar 1, 1995). Nevertheless, the manufacturer still claims that it did not violate FDA regulations in promoting Retin-A. Id at B8.

${ }^{30}$ See David A. Kessler, Drug Promotion and Scientific Exchange: The Role of the Clinical Investigator, 325 New Eng J Med 201, 201 (1991); Charles G. Moertel, Off-Label Drug Use for Cancer Therapy and National Health Care Priorities, 266 JAMA 3031, 3031 (1991); John Carey and Joseph Weber, The FDA Is Growling at Drugmakers, Too: It gets tough with companies that promote drugs for unapproved uses, Bus Week 34, 35 (July 1, 1991).

31 Adams, 24 Seton Hall L Rev at 1409-14 (cited in note 28).

32 Id at 1413.

${ }^{33}$ See David A. Kessler, et al, Therapeutic Class Wars: Drug Promotion in a Competitive Marketplace, 331 New Eng J Med 1350, 1351 (1994).

34 For examples of some possibly dangerous off-label drug uses, see Teri Randall, FDA Scrutinizes "Off-Label" Promotions, 266 JAMA 11, 11 (1991) (tretinoin to treat wrinkles, calcium channel blockers for heart attack patients); Kessler, 15 Harv J Leg at 701-05 (cited in note 26) (indiscriminate use of chloramphenicol, amphetamines to treat depression and obesity, use of estrogens and progestagens during pregnancy, and Depo- 
ber of commentators have suggested that there is a need for more extensive regulatory control over off-label drug uses than the FDA has provided to date. ${ }^{35}$ However, an alternative and less recognized means of controlling off-label drug uses lies in the tort system, specifically in medical malpractice suits against physicians and products liability suits against drug manufacturers. ${ }^{36}$ Although some commentators have concluded that the tort system is not capable of effectively regulating off-label drug uses, their criticisms have focused on medical malpractice liability. ${ }^{37}$ The role of products liability in this area remains largely unexplored. $^{38}$

\section{DRUg PRODUCTS LIABILITY}

There is some debate about how drug products liability fits into the strict products liability regime described by $\S 402 \mathrm{~A}$ of the Restatement (Second) of Torts ${ }^{39}$ and adopted in some form in

Provera as a contraceptive); Shapiro, $73 \mathrm{Nw}$ U L Rev at 818-23 (cited in note 24) (methotrexate to treat psoriasis, chloramphenicol for minor infections or common colds, DES and Depo-Provera as contraceptives).

35 See, for example, Christopher, 48 Food \& Drug L J at 251-52 (cited in note 14); Robin Elizabeth Margolis, Off-Label Uses of Drugs and Medical Devices: Should the FDA Crack Down?, HealthSpan 18, 19 (Jan 1993); Kessler, 15 Harv J Leg 693 (cited in note 26); Shapiro, $73 \mathrm{Nw}$ U L Rev at 822 (cited in note 24).

$3 s$ Even the FDA has taken the position that tort liability is the appropriate source of control for off-label drug uses. See 48 Fed Reg at 26733 (cited in note 25).

${ }^{37}$ This is true of both Christopher, 48 Food \& Drug L J at 260-62 (cited in note 14), and Shapiro, $73 \mathrm{Nw}$ U L Rev at 869-72 (cited in note 24). Note, however, that others have argued that the drug products liability system is generally deficient, presumably with respect to both off-label and approved drug uses. See generally Richard A. Merrill, Compensation for Prescription Drug Injuries, 59 Va L Rev 1 (1973); W. Kip Viscusi, et al, Deterring Inefficient Pharmaceutical Litigation: An Economic Rationale for the FDA Regulatory Compliance Defense, 24 Seton Hall L Rev 1437 (1994).

23 The only extended discussion of the case law appears in Noah, $16 \mathrm{~J}$ Prod \& Toxics Liab 139 (cited in note 7).

Section 402A states:

(1) One who sells any product in a defective condition unreasonably dangerous to the user or consumer or to his property is subject to liability for physical harm thereby caused to the ultimate user or consumer, or to his property, if

(a) the seller is engaged in the business of selling such a product, and

(b) it is expected to and does reach the user or consumer without substantial change in the condition in which it is sold.

(2) The rule stated in Subsection (1) applies although

(a) the seller has exercised all possible care in the preparation and sale of his product, and

(b) the user or consumer has not bought the product from or entered into any contractual relationship with the seller. 
practically all U.S. jurisdictions. ${ }^{40}$ In comment $k$ to $\S 402 \mathrm{~A}$, the Restatement makes the following exception to strict liability for "unavoidably unsafe products":

There are some products which, in the present state of human knowledge, are quite incapable of being made safe for their intended and ordinary use. These are especially common in the field of drugs. . . . Such a product, properly prepared, and accompanied by proper directions and warning, is not defective, nor is it unreasonably dangerous.... The seller of such products, again with the qualification that ... proper warning is given, ... is not to be held to strict liability ....41

As the Restatement indicates, products liability litigation involving the manufacturer of a properly prepared prescription drug generally turns on the sufficiency of the manufacturer's warnings of the drug's risks. ${ }^{42}$

Restatement (Second) of Torts $\S 402 A$ (1965).

40 2 American Law of Products Liability $3 d \S 16: 1$ at 11 (Law Co-op 1987 \& Supp 1995).

41 Restatement (Second) of Torts $\$ 402 \mathrm{~A}$ comment $\mathrm{k}$ (cited in note 39) (first emphasis added).

42 See Marden G. Dixon, 2 Drug Product Liability $\S 14.01$ at 14-3 (Matthew Bender 1994); Lane D. Bauer and Laura D. Stith, The Duty to Warn, in Donald E. Vinson and Alexander H. Slaughter, eds, Products Liability: Pharmaceutical Drug Cases 120, 149-52 (McGraw-Hill 1988).

A minority of jurisdictions have refused to adopt comment $k$ with respect to all prescription drugs and instead hold manufacturers strictly liable for injuries caused by at least some drugs. Bauer and Stith, Duty to Warn at 149-52. A few commentators have advocated a strict liability approach to all drug products liability. See, for example, Merrill, 59 Va L Rev at 107-10 (cited in note 37); Patty Coleman Selker, Comment, An Escape from Strict Liability: Pharmaceutical Manufacturers' Responsibility for Drugrelated Injuries under Comment $k$ to Section 402A of the Restatement (Second) of Torts, 23 Duquesne L Rev 199, 219 (1984). Others have said that the protection afforded by comment $\mathrm{k}$ ought to apply only to manufacturers of exceptionally beneficial drugs. See, for example, Yvonne M. Driessen, Note, Products Liability-A Case-by-Case Approach to Determining Strict Liability in Prescription Drug Cases-Hahn v. Richter, 628 A.2d 860 (Pa. Super. Ct. 1993), appeal docketed, No. 32 E.D. Appeal Docket (Pa. Apr. 25, 1994), 67 Temple L Rev 883, 898-902 (1994); George H. King, Note, A Prescription for Applying Strict Liability: Not All Drugs Deserve Comment $k$ Immunization, Brown v. Superior Court, 44 Cal. $3 d$ 1049, 751 P.2d 470, 245 Cal. Rptr. 412 (1988), 21 Ariz St I. J 809, 831 (1989); Tim Moore, Comment, Comment $k$ Immunity to Strict Products Liability: Should All Prescription Drugs Be Protected?, 26 Houston L Rev 707, 736 (1989).

This Comment does not discuss strict drug products liability since it is a minority position and presents few of the same conceptual issues as liability under comment $k$. But see note 63 on strict drug products liability with respect to off-label drug uses. This Comment also does not discuss drug products liability suits alleging defective design or manufacture. As a practical matter, such suits are very uncommon. Dixon, 2 Drug Product Liability $\S \S 14.01,14.04[1]$ at 14-4, 14-68; Bauer and Stith, Duty to Warn at 126-38. 
The general rule is that manufacturers are only liable for failure to warn of risks of which they know or should know. ${ }^{43}$ In determining which risks these are, manufacturers are held to the standard of experts in the field. ${ }^{44}$ FDA regulations require that drug manufacturers carefully monitor reports from physicians-whether made directly to manufacturers or published in the medical literature-regarding injuries related to their drugs. ${ }^{45}$ The FDA also requires manufacturers to keep abreast of scientific developments regarding their drugs. ${ }^{46}$ Courts have thus said that a drug's manufacturer has at least constructive, if not actual, knowledge of all documented risks associated with the drug. ${ }^{47}$ Manufacturers also have a duty to conduct postmarketing studies on the safety of their drugs and to monitor for and investigate possible undetected risks. ${ }^{48}$

Given that a drug manufacturer knew or should have known of a particular risk, liability depends on the adequacy of the manufacturer's warning. A warning's adequacy depends on fac-

More importantly, they present no issues of special interest in the context of off-label drug uses.

${ }^{43}$ See Dixon, 2 Drug Product Liability \$§ 14.02[3][a], 14.06[1] at 14-31, 14-110 (cited in note 42); Bauer and Stith, Duty to Warn at 139 (cited in note 42); 6 American Law of Products Liability $3 d \$ 89: 3$ at 10 (Law Co-op 1987 \& Supp 1995); Richard C. Ausness, Unavoidably Unsafe Products and Strict Products Liability: What Liability Rule Should be Applied to the Sellers of Pharmaceutical Products?, 78 Ky L J 705, 733 (1989-90); Kathleen H. Wilson, Note, The Liability of Pharmaceutical Manufacturers for Unforeseen Adverse Drug Reactions, 48 Fordham L Rev 735, 745-49 (1980).

44 Dixon, 2 Drug Product Liability \$ 14.02[3][a] at 14-34 (cited in note 42); Bauer and Stith, Duty to Warn at 139-40 (cited in note 42).

45 FDA, Applications for FDA Approval to Market a New Drug or an Antibiotic Drug, 21 CFR § 314.80(b) (1995).

48 Id.

17 See, for example, Barson v E.R. Squibb \& Sons, Inc., 682 P2d 832, 835-36 (Utah 1984); Dalke v Upjohn Co., 555 F2d 245, 248 (9th Cir 1977); McEwen v Ortho Pharmaceutical Corp, 270 Or 375, 528 P2d 522, 528-29 (1974). See also Dixon, 2 Drug Product Liability $\$ 14.04$ [2][c] at 14-75 (cited in note 42); Wilson, Note, 48 Fordham L Rev at 749 (cited in note 43).

4 FDA, New Drugs, 21 CFR $\$ 310.303$ (1995), requires long-range postmarketing studies for certain drugs, although FDA regulations are unclear about the extent to which follow-up studies are otherwise required. Courts and commentators have, however, said that a drug manufacturer's general duty to conduct studies to evaluate risks continues after a drug is on the market. See Kociemba $v$ G.D. Searle \& Co., 707 F Supp 1517, 152829 (D Minn 1989); Medics Pharmaceutical Corp v Newman, $190 \mathrm{Ga}$ App 197, 378 SE2d 487, 489 (1989); Dixon, 2 Drug Product Liability § 14.04[2][c]-[d] at 14-76 to 14-82 (cited in note 42); G. Marc Whitehead and Thomas E. Sanner, The Duty to Test, in Donald E. Vinson and Alexander H. Slaughter, eds, Products Liability: Pharmaceutical Drug Cases 206, 214-16 (McGraw-Hill 1988); 1 American Law of Products Liability $3 d \S 11: 19$ at 28 (Law Co-op 1987 \& Supp 1995); Ausness, $78 \mathrm{Ky} \mathrm{L} \mathrm{J} \mathrm{at} 733$ (cited in note 43); Gerald A. Faich, Adverse Drug Experience Reporting and Product Liability, 41 Food Drug Cosm L J 444,445 (1986). 
tors such as whether the risk was great enough to warrant a warning at all and whether the warning was given in an appropriate manner. Such questions inevitably import negligence issues into drug products liability, since courts are ultimately asking whether the manufacturer's warning was reasonable.

Much conceptual confusion surrounds the relationship between strict products liability and liability for failure to warn. Some courts have concluded that, with regard to the duty to warn, strict liability and negligence are indistinguishable. ${ }^{49}$ However, although the distinction between strict liability and negligence may be of no practical significance in the vast majority of failure-to-warn cases, failure to warn need not reduce to simple negligence. ${ }^{50}$ Even though the adequacy of a warning may be a matter of its reasonableness, a nonnegligent manufacturer could nonetheless fail to give an adequate warning. ${ }^{51}$

A prescription drug manufacturer is usually not required to warn patients of risks associated with using a drug; rather, the manufacturer must warn the prescribing physician, who acts as a "learned intermediary" between the manufacturer and the patient. ${ }^{2}$ The rule that emerges, then, from current drug products

49 In the context of drug products liability, see, for example, Enright $v$ Eli Lilly \& Co., 77 NY2d 377, 568 NYS2d 550, 555-56 (1991); Werner v Upjohn Co., 628 F2d 848, 858 (4th Cir 1980). See also James A. Henderson and Aaron D. Twerski, Doctrinal Collapse in Products Liability: The Empty Shell of Failure to Warn, 65 NYU L Rev 265, 271-78 (1990). Note, too, that $\S 388$ of the Restatement (Second) of Torts, which predates $\S 402 \mathrm{~A}$ and comment $k$, describes the duty to warn in straightforward negligence terms. It provides that the supplier of a chattel that is known to be dangerous will be liable for injuries suffered by the chattel's users if the supplier has reason to believe that the users will be unaware of the risk and the supplier "fails to exercise reasonable care to inform them of its dangerous condition or of the facts which make it likely to be dangerous." Restatement (Second) of Torts $\S 388$ (cited in note 39 ).

50 Indeed, the language of comment $k$ suggests this point. Comment $k$ says that the seller of an unavoidably unsafe product is not subject to strict liability if the product is properly prepared and accompanied by a "proper warning." See Restatement (Second) of Torts $\S 402 A$ comment $k$ (cited in note 39 ). Presumably, if the product is not accompanied by such a warning-for whatever reason and regardless of the seller's negligence-the seller is still subject to strict liability.

${ }^{51}$ For example, a drug warning might not mention an important risk because the manufacturer relied on studies by generally reliable researchers who failed to detect the risk due to a clerical error. The warning might thus be unreasonable, subjecting the manufacturer to liability, even though the manufacturer was not negligent in formulating the warning.

52 See Dixon, 2 Drug Product Liability $\S 14.02[2][b]$ at 14-21 to 14-27 (cited in note 42); Bauer and Stith, Duty to Warn at 164-68 (cited in note 42); 6 American Law of Products Liability $3 d \S 89: 6$ at 13-15 (cited in note 43 ). While some commentators have suggested that the learned intermediary doctrine is on the wane and that courts are favoring direct warnings to patients, see, for example, Virginia H. Castleberry, Note, Hill v. Searle Laboratories: The Decline of the Learned Intermediary Doctrine in Favor of Direct Patient 
liability doctrine is this: a drug's manufacturer will be liable for injuries caused by use of the drug if the manufacturer, as an expert in the field, knew or should have known of the risk of the injury and failed adequately to warn the prescribing physician. ${ }^{53}$

Of course, the FDA must approve the language of the package insert with which a drug manufacturer warns physicians about the risks associated with a drug. ${ }^{54}$ Thus, when a court finds that a manufacturer's warning is inadequate, it does so in spite of the FDA's prior approval of that warning. ${ }^{55}$ Some commentators have argued that compliance with FDA regulations should be a complete defense in drug products liability actions. ${ }^{56}$ Others have claimed that the FDA's regulation of drug warnings preempts state tort law, so liability under state law cannot rest on the inadequacy of an FDA-approved warning. ${ }^{57}$ Courts have

Warnings of Drug Product Risks, 43 Ark L Rev 821 (1990); Paul D. Rheingold, The Expanding Liability of the Drug Manufacturer to the Consumer, 40 Food Drug Cosm L J 135 (1985), the learned intermediary doctrine remains the rule rather than the exception. See N. Kathleen Strickland, Current Applications and Limitations on the Learned Intermediary Rule, For the Defense 14, 18 (Aug 1993). Courts have held, however, that it does not apply to warnings regarding birth control pills, certain vaccines, and other drugs that are commonly dispensed with little involvement by a physician. Id at 15-18.

5 Draft versions of the next revision of the Restatement explicitly adopt this regime, including the learned intermediary rule, for drug products liability. See Restatement (Third) of Torts: Products Liability $\$ 8$ (Tentative Draft No 2, Mar 13, 1995). The American Law Institute adopted $\$ 8$ at its May 1995 meeting. ALI Approves Product Liability Draft, Takes First Steps on New Family Law Project, 63 USLW 2734, 2735 (May 30, 1995).

st See text accompanying notes 8-10.

i Indeed, many courts have explicitly rejected the argument that a drug manufacturer's warnings are adequate just because they comply with FDA requirements. See, for example, MacGillivray v Lederle Laboratories, 667 F Supp 743, 746 (D NM 1987); Martinkovic v Wyeth Laboratories, Inc., 669 F Supp 212, 217 (N D III 1987); Bristol-Myers Co. $v$ Gonzales, 548 SW2d 416, 423 (Tex Ct App 1976), rev'd on other grounds, 561 SW2d 801 (Tex 1978); Michael $v$ Warner/Chilcott, 91 NM 651, 579 P2d 183, 186 (NM Ct App 1978). See also Dixon, 2 Drug Product Liability $\$ 14.04$ [3][c] at $14-88$ to 14-91 (cited in note 42 ).

Moreover, in at least one case, a court held a drug manufacturer liable for failure to warn even after the manufacturer attempted to change the warning but was prevented from doing so by the FDA. See Wooderson v Ortho Pharmaceutical Corp, 235 Kan 387, 681 P2d 1038, 1057 (1984) (affirming judgment against a drug manufacturer, even though the FDA had apparently rejected a proposal by the manufacturer to include a warning of the risk in question on the package insert).

ts See, for example, Viscusi, et al, 24 Seton Hall L Rev at 1478-79 (cited in note 37).

57 See, for example, Brian J. Donato and Mary Beth Neraas, Federal Preemption of Product Liability Claims Involving Drugs and Medical Devices Regulated Under the Federal Food, Drug, and Cosmetic Act, 48 Food \& Drug L J 305, 319 (1993). State products liability law regarding medical devices, unlike state drug products liability law, is expressly preempted by federal statute. See Lars Noah, Amplification of Federal Preemption in Medical Device Cases, 49 Food \& Drug L J 183, 183 (1994) (rejecting the argument that the rationale for finding federal preemption of medical device products liability 
generally rejected such arguments, however, and they continue to base manufacturer liability on the inadequacy of warnings that the FDA has approved and that the manufacturer could not change without the FDA's permission. ${ }^{58}$

Although the current system may not be ideal, there are grounds for thinking that it works reasonably well. Since drug manufacturers already have the best information regarding the risks associated with their drugs ${ }^{59}$ they should be provided with strong incentives to be aware of those risks and to lobby the FDA vigorously for permission to modify warnings appropriately. Moreover, commentators generally agree that the FDA rarely rejects a proposed warning without good reason..$^{60}$ And finally, the fact that the FDA approved a manufacturer's warning and even rejected a proposed modification should often persuade a jury to reject a plaintiff's contention that the warning was inadequate. ${ }^{61}$

\section{PRODUCTS LIABILITY FOR INJURIES CAUSED BY OFF-LABEL DRUG USES}

Off-label uses of prescription drugs should present no special products liability issues when a plaintiff, injured by an off-label

claims extends to drug products liability).

${ }_{53}$ In response to the apparent unfairness of this system, one might note that $21 \mathrm{CFR}$ $\S 314.70(c)(2)(i)$ allows drug manufacturers to change labeling " $[t]$ o add or strengthen a contraindication, warning, precaution, or adverse reaction" before receiving FDA approval for the change. See $M c E w e n, 528$ P2d at 534-35 (applying a predecessor to § 314.70). See also In re Tetracycline Cases, 747 F Supp 543, 549 (W D Mo 1989) (relying on the same regulation to find no federal preemption of state failure-to-warn claims); Feldman $v$ Lederle Laboratories, $125 \mathrm{NJ}$ 117, 592 A2d 1176, 1192-94 (1991) (suggesting that the FDA allowed manufacturers to add warnings to drug labeling without seeking prior permission even before such regulations were in force). However, Richard M. Cooper, Drug Labeling and Products Liability: The Role of the Food and Drug Administration, 41 Food Drug Cosm L J 233, 235 (1986), argues that courts overestimate manufacturers' ability to alter warnings and that, in practice, the FDA has total control over manufacturers' warnings of the risks of using their drugs.

${ }_{59}$ See text accompanying notes $\mathbf{4 5 - 4 8}$.

60 See Viscusi, et al, 24 Seton Hall L Rev at 1448, 1469 n 118 (cited in note 37) (praising the FDA's institutional competence and claiming that it would not prevent a manufacturer from including a warning without good reason); Thomas Scarlett, The Relationship Among Adverse Drug Reaction Reporting, Drug Labeling, Product Liability, and Federal Preemption, 46 Food Drug Cosm L J 31, 36, 42 (1991) (doubting that the FDA would force a drug manufacturer to retract an addition to a package insert and denying that the FDA can be accused "of trying to keep a lid on negative information"); Merrill, 59 Va L Rev at 116 (cited in note 37) ("The FDA frequently seems to favor safety at any cost....").

${ }_{61}$ See Noah, $16 \mathrm{~J}$ Prod \& Toxics Liab at 158 (cited in note 7); Scarlett, 46 Food Drug Cosm L $\mathrm{J}$ at 37 (cited in note 60 ). 
use, claims that a drug's manufacturer failed to warn of a risk that is common to both approved and off-label uses of the drug. ${ }^{62}$ Questions arise, however, when a plaintiff alleges that a manufacturer failed to warn of a risk that is unique to off-label uses of the drug. ${ }^{63}$ This Section discusses cases in which courts have confronted this situation, draws out the general rules behind the courts' decisions, and evaluates the positions they have taken.

The cases fall into five broad categories. At the extremes, one court has said that manufacturers are never liable for failure to warn of risks associated with off-label drug uses, while another has declined to recognize any distinction at all between off-label and approved drug uses. Other courts have taken intermediate positions, imposing liability only for failure to warn of risks associated with certain off-label uses. One approach identifies the offlabel uses requiring warnings with reference to the roles drug manufacturers play with respect to various uses. Another position holds manufacturers liable only when the off-label use in question is widely accepted by the medical community. A final approach applies the doctrine of foreseeable misuse to off-label drug use.

\section{A. No Liability for Off-Label Uses}

In Robak $v$ Abbott Laboratories, the plaintiff was injured when she took the drug Omniflox for sinusitis, although the FDA had not approved the drug to treat sinusitis or any other upper respiratory tract infection. ${ }^{64}$ The plaintiff contended that the drug's manufacturer was liable for failure to warn of the risks

62 But see Robak $v$ Abbott Laboratories, 797 F Supp 475 (D Md 1992), which could be interpreted to hold that a plaintiff's off-label use of a drug bars all recovery. See text accompanying notes $64-68$.

63 The situation is not much simpler in jurisdictions that hold manufacturers strictly liable for injuries caused by prescription drugs. A plaintiff's misuse of a product is typically a defense to strict liability, especially if the misuse is unforeseeable. See 3 American Law of Products Liability 3d $\$ \S 42: 11-42: 14$ at 26-32 (Law Co-op 1987 \& Supp 1995). Thus, in strict drug products liability jurisdictions, drug manufacturers will attempt to cast off-label drug uses as misuses. Courts must then determine which off-label uses are indeed misuses and which are legitimate uses, and their treatment of this issue should mirror the analysis-in jurisdictions that apply comment $k-0$ whether a given off-label use is such that manufacturers must warn of its risks. So, although the following discussion focuses on issues surrounding failure-to-warn claims, much of it could thus be translated into strict liability terms.

6s 797 F Supp 475, 476 (D Md 1992). 
associated with that off-label use of the drug, but the court dismissed the claim, reasoning that:

When a physician, as a learned intermediary, has been provided with the indications for which a drug is effective, but prescribes it for a non-indicated use, the manufacturer should not be exposed to tort liability for any defect in labeling .... [W] [Wen a physician decides to dispense an ethical drug for a condition for which it is not indicated, the manufacturer should not be held responsible. ${ }^{65}$

The plaintiff in Robak presented evidence that the manufacturer had represented the drug to the prescribing physician as an effective treatment for a wide range of conditions beyond those for which it was approved. ${ }^{66}$ Nevertheless, the court reached its conclusion without addressing such issues as the manufacturer's promotional efforts or the manufacturer's knowledge of off-label uses. "[T] effects that might be associated with misuse of the product, i.e., its use for treatment of a non-indicated condition."

The holding of Robak, then, is that a manufacturer is never liable for failure to warn of risks unique to off-label uses of its drugs. Indeed, some of the quoted language suggests the even stronger holding that a plaintiff injured by an off-label drug use will not recover from the manufacturer even if the risk is common to both off-label and approved uses, since off-label drug use is always the sort of misuse that prevents any recovery by a plaintiff. $^{68}$

${ }_{65}$ Id, citing Weinberger $v$ Bristol-Myers Co., 652 F Supp 187 (D Md 1986). "Indicated" conditions are those for which the FDA has approved the drug.

66 797 F Supp at 476.

67 Id, citing Higgins $v$ E.I. DuPont de Nemours, Inc., 671 F Supp 1055 (D Md 1987), aff'd, 863 F2d 1162 (4th Cir 1988).

${ }_{68}$ The court in Mulder $v$ Parke Davis \& Co., 288 Minn 332, 181 NW2d 882, 885 (1970), reached a similar conclusion when the prescribing physician deliberately deviated from a drug's approved dosage. The court stated that the physician's decision not to follow the manufacturer's instructions "constitute[d] a break in causation which exonerate[d] the manufacturer from any liability." Id, quoting Magee $v$ Wyeth Laboratories, Inc., 214 Cal App 2d 340, 29 Cal Rptr 322, 328 (1963). It was thus unnecessary for the court to address the adequacy of the manufacturer's warnings. Note, however, that in Mulder, the manufacturer's warning was causally irrelevant because the physician was aware of the risks in question. $181 \mathrm{NW} 2 \mathrm{~d}$ at 885 . It is unclear how the court would have decided the case had the physician been unaware of the risks.

Also of interest is Proctor $v$ Davis, 1994 Ill App LEXIS 995, *10-11, in which the plaintiff became blind in one eye after receiving a periocular injection (that is, an injection near the eye) of the drug Depo-Medrol. In that case, the court held that the manufacturer was not liable, citing the knowledge of both the specialized medical community and the 
Releasing manufacturers from any duty to warn of risks due to off-label drug uses is a serious mistake. Many patients rely on off-label drug therapies, and drug manufacturers, because of their strong monitoring positions, ${ }^{69}$ are the parties in the best position to provide important warnings of the risks to which those patients are exposed. In other words, with respect to many injuries caused by off-label drug uses, drug manufacturers are, due to their superior ability to warn, the cheapest cost avoiders.

Imposing a duty on manufacturers to warn of the risks of offlabel drug uses does not, as might be feared, turn manufacturers into insurers for physicians who carelessly prescribe dangerous off-label treatments or who negligently misprescribe drugs and later characterize their mistakes as off-label treatments. Injured patients can still bring medical malpractice suits against negligent physicians. Moreover, a manufacturer found liable will generally have contribution and indemnity claims against any physician whose negligence played a role in the plaintiff's injuries. ${ }^{70}$ Some courts have even said that a physician's negligence, especially if unforeseeable, can absolve a drug manufacturer of all liability for failure to warn of the risks associated with the use of its drug. ${ }^{71}$ And finally, of course, manufacturers can always protect themselves by adequately warning physicians of the risks of off-label drug uses.

Nevertheless, one might feel that it is unjust to hold a drug manufacturer liable for injuries caused by an off-label drug use if the manufacturer made no effort to promote the off-label use and,

prescribing physician of the risk in question. Id $* 35$. However, the court also distinguished a case relied on by the dissent by saying that "Mahr is simply not on point because, unlike the off-label use of Depo-Medrol at issue here, the [drug] in Mahr was used by the decedent in an on-label manner.... Thus, the duty described in Mahr was the duty to warn physicians of the adverse affects associated with the on-label use of a drug." Id $* 36$. The court did not elaborate, but it apparently thought that a drug manufacturer's duty to warn of the risks of an off-label drug use was significantly weaker than its duty to warn of the risks of an approved use.

Proctor may not be over. The appellate court in that case has issued a certificate of importance, giving the parties the right to appeal to the Illinois Supreme Court. See Carol McHugh Sanders, Record-breaking case sent to high court, Chi Daily L Bull 1 (Oct 27, 1995).

${ }^{69}$ See text accompanying notes $45-48$.

${ }^{70}$ See generally Charles F. Preuss, Measures of Liability, in Donald E. Vinson and Alexander H. Slaughter, eds, Products Liability: Drug Cases 303, 322-30 (McGraw-Hill 1988).

${ }_{11}$ For example, Peterson v Parke Davis \& Co., 705 P2d 1001, 1003 (Colo Ct App 1985) (holding that the adequacy of warnings is irrelevant when attending physician is negligent); Reeder $v$ Hammond, 125 Mich App 223, 336 NW2d 3, 5-6 (1983) (recognizing that the intervening negligence of a physician could preclude liability for failure to warn). 
indeed, would have preferred that physicians not prescribe the drug for that use. But this concern seems misplaced. Manufacturers can often shield themselves from liability in such cases by simply warning physicians against inadvisable off-label uses. Additionally, since manufacturers are the parties in the best position to prevent injuries by warning of the risks of off-label drug uses, it is appropriate to impose on them a duty to do so.

In the long run, of course, if manufacturers are held liable for failure to warn of risks associated with off-label drug uses, they may end up paying for injuries caused by off-label uses that are beyond their control. This, in turn, would diminish manufacturers' ability to manage their expected liability. However, injuries caused by off-label uses of prescription drugs under the supervision of nonnegligent physicians are among the social costs of making the drugs available. It is, after all, certainly better to allow competent physicians to prescribe drugs for off-label uses than to ban such uses altogether. ${ }^{72}$ From a social standpoint, it is desirable that manufacturers, as the parties in the best position to minimize these social costs through warnings, should bear them.

One might also argue that if manufacturers are held liable for failure to warn of risks of off-label drug uses, they will respond by overwhelming physicians with more warnings than the physicians can process, thereby making all of the warnings ineffective. While there is some debate about whether such "information overload" is ever a serious danger, ${ }^{73}$ it is especially unlikely to pose a serious problem in this context. First, as professionals, physicians should be able to examine and respond to a large number of detailed warnings, and the threat of malpractice liability for failing to heed manufacturer warnings should give them appropriate incentives to take even the most complex warnings seriously. Second, the FDA must approve all manufacturer warnings, ${ }^{74}$ and the FDA is sensitive to the possibility of overwarning, and frowns upon warnings of risks that are not

72 Such a ban would probably have some beneficial effects, since manufacturers would respond by seeking FDA approval for certain off-label drug uses, and they would then be required to study the safety and efficacy of those uses. However, many valuable off-label uses, especially those that are important only to relatively small groups of patients, would likely remain unapproved for economic reasons. A ban on off-label drug uses would make such uses unavailable to many patients who need them.

${ }_{73}$ See Howard Latin, “Good" Warnings, Bad Products, and Cognitive Limitations, 41 UCLA L Rev 1193, 1211-15 (1994).

${ }^{74}$ See text accompanying notes 8-10. 
scientifically substantiated..$^{75}$ Finally, courts could prevent manufacturers from overwarning by holding that a warning can be inadequate because it has been diluted by being buried among too many other warnings. ${ }^{76}$

By far the most significant concern about holding manufacturers liable for failure to warn of risks of off-label drug uses is that such liability could dramatically increase drug manufacturers' costs, thereby affecting their behavior in undesirable ways. ${ }^{77}$ Liability for injuries caused by off-label drug uses could deter manufacturers from researching or funding research into valuable, new off-label uses: unless it expects a very great increase in sales, a drug manufacturer may well prefer not to encourage off-label uses that could expose it to additional liability. Moreover, any increase in liability will increase the costs of marketing prescription drugs. This could lead manufacturers to withdraw socially valuable drugs from the market, especially those that are only marginally profitable, and not to develop drugs in the first place if the anticipated profits are not especially large. Finally, as manufacturers' expenses go up, their likely response is to raise prices, increasing the costs of medical care and limiting poorer patients' access to drugs.

${ }_{75}$ See Viscusi, et al, 24 Seton Hall L Rev at 1479 (cited in note 37) ("[A] determination by the [FDA] that a warning is inappropriate generally will occur only in those situations where the harm is speculative, or when serious issues of dilution or brevity are presented in labeling."); Noah, $16 \mathrm{~J}$ Prod \& Toxics Liab at 163 (cited in note 7); Scarlett, 46 Food Drug Cosm L J at 35-36 (cited in note 60); Bauer and Stith, Duty to Warn at 124 (cited in note 42). See also 21 CFR $\$ 201.57$ (d) ("Known hazards and not theoretical possibilities shall be listed" as contraindications on the label.).

${ }^{76}$ Courts have recognized the risk of overwarning. See, for example, Thomas $v$ Hoffman-LaRoche, Inc., 949 F2d 806, 816 n 40 (5th Cir 1992); Finn v G.D. Searle \& Co., 35 Cal 3d 69, 200 Cal Rptr 870, 876 (1984); Dunn v Lederle Laboratories, 121 Mich App 73, 328 NW2d 576, 580-81 (1982). However, courts have been hesitant to find liability due to overwarning. See Steven Garber, Product Liability and the Economics of Pharmaceuticals and Medical Devices 134 (Rand 1993) (finding "no indication that warnings to physicians have been ruled legally inadequate because they are too detailed [ ] or extensive"). It would certainly be a mistake to find such liability too readily, as drug manufacturers might then be liable whether or not they include warnings of scientifically substantiated risks. But the possibility of liability due to overwarning should nevertheless deter manufacturers from including warnings for every conceivable risk, regardless of the scientific evidence. More importantly, drug manufacturers have significant control over the design and organization of labels, and the threat of overwarning liability should give them incentives to create labels such that all significant risks will come to the attention of a responsible physician.

77 Holding manufacturers liable should not, however, influence physicians' prescribing practices. Nonnegligent physicians will face no additional liability and therefore should be undeterred from prescribing drugs for off-label uses. 
Such commonsense suppositions about the effects of drug products liability turn out to be difficult to verify empirically as general propositions. ${ }^{78}$ Nevertheless, they do represent important concerns about any proposal that would impose significant liability on drug manufacturers, since it is clear that high levels of manufacturer liability would have such negative consequences in at least some cases. ${ }^{79}$

Furthermore, in this context, tort liability does not play its idealized roles of ensuring that all and only socially efficient drugs are on the market and of adjusting prices so that only those consumers for whom the benefits outweigh the risks use any given drug. The unpredictability surrounding the risks associated with prescription drugs, the unpredictability of drug products liability litigation, and the inaccuracy of the perceptions of expected liability and profitability on the part of drug manufacturers' corporate decision makers are simply too great. ${ }^{80}$

While excessive manufacturer liability may thus impose real costs on society, in many cases it is still fully appropriate to hold drug manufacturers liable for failure to warn of risks of off-label drug uses. If a drug manufacturer knows of a significant risk of an off-label drug use and could inexpensively shield itself from liability by simply warning physicians, then there is no reason not to give the manufacturer strong incentives to do so. Although any proposal for manufacturer liability must be sensitive to the adverse consequences of imposing high costs on drug manufacturers, the Robak court's position that drug manufacturers should never face liability for injuries caused by off-label drug uses is unjustifiable.

\section{B. No Distinction Between Off-Label and Approved Uses}

At the opposite extreme from Robak is Hahn $v$ Richter, in which the court drew no distinction between risks associated with off-label drug uses and those associated with approved uses. ${ }^{81}$ Hahn involved injuries due to the off-label intrathecal injection (that is, injection directly into the spine) of the drug DepoMedrol. ${ }^{82}$ The court held that "the trial court properly instructed

78 See, for example, Garber, Product Liability at 167, 172-75 (cited in note 76).

79 See id at 166-67, 172-74.

${ }^{80}$ See id at 172-74.

81 $427 \mathrm{~Pa}$ Super 130, 628 A2d 860 (1993), app granted, $537 \mathrm{~Pa} 650,644$ A2d 736 (1994).

82628 A2d at 861-62. 
the jury to examine [the manufacturer's] conduct regarding the dangers of the intrathecal administration of Depo-Medrol in light of the 'reasonableness' standard set forth in Section 388" of the Restatement..$^{83}$ Although $\S 388$ refers only to risks of physical harm "caused by the use of the chattel in the manner for which ... it is supplied, ${ }^{\prime 84}$ and the court said that a drug manufacturer "is liable only if it fails to exercise reasonable care to inform physicians ... of the facts which make [a drug] likely to be dangerous for its intended use, ${ }^{185}$ the Hahn court made no suggestion that the trial court should have dismissed the claims against the drug manufacturer for injuries caused by an off-label use. Instead, the court approved of the trial court's general reasonableness instructions, instructions that did not distinguish between off-label and approved drug uses. ${ }^{86}$

The rule that emerges from Hahn, then, is that a drug manufacturer must exercise reasonable care to warn of risks associated with any use of a drug, regardless of whether the use is approved, off-label, or even clearly inappropriate. The court did not discuss what counts as "reasonable care," presumably leaving that question to juries.

The weakness of the Hahn rule is that it sanctions virtually unlimited manufacturer liability for injuries related to off-label drug uses. Faced with a terribly injured plaintiff, a jury may well find unreasonable a drug manufacturer's failure to warn of any risk of virtually any off-label drug use. As described above, the costs of such broad liability threaten to deter manufacturers from investigating off-label uses, to force valuable drugs off the market, and to raise drug prices.

While it may seem unlikely, it is also possible that juries would apply the Hahn court's reasonableness standard in a more restrained manner and limit manufacturer liability to those cases in which the manufacturer really could have warned easily. But even without high actual liability costs, the uncertainty of such an open-ended standard and the possibility of enormous liability would still have negative consequences.

First, the uncertainty would encourage litigation, since plaintiffs would always have some chance of winning a large judg-

E3 Id at 868. Restatement (Second) of Torts $\S 388$ (cited in note 39) requires the manufacturer of a product known to be dangerous to "exercise reasonable care to inform [users] of its dangerous condition or of the facts which make it likely to be dangerous."

s. Restatement (Second) of Torts $\$ 388$ (cited in note 39) (emphasis added).

Hahn, $628 \mathrm{~A} 2 \mathrm{~d}$ at 866 (emphasis added).

*s Id at 867-68. 
ment, and would also raise the costs of litigation. Such litigation costs, apart from actual liability, would significantly burden manufacturers and could, just like liability costs, deter innovation, force drugs off the market, and raise drug prices. ${ }^{87}$

Second, manufacturer behavior and pricing decisions depend not on actual liability and litigation costs, but on corporate decision makers' perceptions of expected liability and litigation costs and of the expected profitability of a drug. Such perceptions are naturally imperfect to begin with, and when there is considerable uncertainty as exists under the Hahn rule, decision makers are likely to overestimate costs. ${ }^{88}$

A preferable position would impose liability on manufacturers in a manner that gives them strong incentives to warn of risks when appropriate, but that does not impose excessive costs on them. Such a position should distinguish some class of cases in which drug manufacturers have a duty to warn of risks of offlabel drug uses from other cases in which they have no such duty, drawing the distinction in such a way as to preserve manufacturers' incentives to warn while limiting their liability and litigation costs. The intermediate positions discussed below can be seen as efforts to craft just such a distinction.

\section{Manufacturer's Role}

One approach, represented by Miles Laboratories, Inc. $v$ Superior Court, ${ }^{89}$ distinguishes the situations in which a manufacturer must warn of the risks of an off-label drug use from those in which it has no such duty by focusing on the manufacturer's role with respect to the use in question. In Miles Laboratories, the plaintiff sued a number of drug manufacturers for failing to provide an adequate warning of the risks of using DES to prevent miscarriages, which the FDA had only approved on an experimental basis. ${ }^{90}$ One of the defendants, Miles Laboratories,

${ }^{87}$ See Garber, Product Liability at 93 (cited in note 76) (claiming that manufacturers have taken drugs off the market due to litigation and insurance costs even when they could successfully defend in products liability litigation).

${ }^{8}$ See id at 68-76, 184-85. Of course, corporate decision makers might also underestimate the costs associated with a drug. Assuming, however, that corporate decision makers are risk averse, they should more often overestimate than underestimate. In any case, underestimation of costs would just compound the inefficiencies of the Hahn regime. Manufacturers would remove socially valuable drugs from the market due to actual or perceived excessive costs, while at the same time leaving other, inefficient drugs on the market due to erroneous low estimates of costs.

E9 133 Cal App 3d 587, 184 Cal Rptr 98 (1982).

so $184 \mathrm{Cal}$ Rptr at 100. 
moved for summary judgment, claiming that, although other manufacturers had sold DES as a miscarriage preventative, it had developed its brand of DES, Stilphostrol, solely for the treatment of prostatic cancer in men and that it did not "in any way participate ... in the manufacture, marketing, promotion or sale of DES for use by women." ${ }^{.91}$ The plaintiff alleged in opposition that it was common knowledge that pharmacists often filled women's DES prescriptions with whatever brand they had on hand, including Stilphostrol..$^{92}$ The court held that Miles would be liable if the plaintiff's allegations were true ${ }^{93}$ Although it expressed sympathy for the idea that manufacturer liability should be limited to a drug's intended uses, the court was "compelled to take a broader view" by the allegations that Miles "knew or should have known that its drug was being used as a miscarriage preventative and did nothing to prevent such use and by acquiescing in such use claimed for itself a share of the market.".94 The liability rule of Miles Laboratories, then, is that a manufacturer will be liable for failure to warn of risks of an off-label drug use if the manufacturer knew or should have known of the offlabel use and that use accounted for a significant portion of the manufacturer's sales of the drug. ${ }^{95}$

Variants of this position would hold drug manufacturers liable for failure to warn of risks of off-label drug uses only if they deliberately promoted the uses, or only if they deliberately promoted and significantly profited from the uses. At least one court initially suggested this approach, although it later modified its opinion and decided the case without discussing the issue. ${ }^{96}$

91 Id at 101-02.

92 Id at 102.

93 Id.

94 Id at 103.

95 The use of Stilphostrol as a miscarriage preventative was off-label, although other brands of DES had been approved by the FDA for that use on an experimental basis. Since Miles never sought approval for Stilphostrol for any use other than the treatment of male prostatic cancer, there is no reason to think that the court's holding would not also apply to more typical off-label drug uses, for which no competing manufacturers have secured even limited FDA approval.

${ }_{96}$ The original opinion in Proctor $v$ Davis, 1994 WL 284578, *10 (Il Ct App), held that the manufacturer had a duty to warn of risks of an off-label drug use if the manufacturer "invited and solicited the off-label use of its product[,] . . represented that its drug was safe and suitable for the off-label use[,] ... and . . . both created the risk and reaped the profit for the off-label use of its drug." However, this portion of the opinion was deleted when the court modified its opinion on rehearing and held that the defendant drug manufacturer was not liable at all because the specialized medical community and, apparently, the prescribing physician knew of the risks in question. Proctor $v$ Davis, 1994 Ill App LEXIS 995, *35. 
Such approaches should avoid many of the possible negative consequences of manufacturer liability for injuries due to off-label drug uses. First, they restrict liability to relatively profitable offlabel uses, in which innovation will not be easily discouraged. Moreover, they confine liability to off-label uses that the manufacturer promotes, thereby placing it under the manufacturer's control. However, the rules they endorse go too far, inappropriately shielding drug manufacturers from liability in many cases where potential liability would result in the dissemination of important warnings without significantly increasing manufacturers' costs.

From a products safety and liability standpoint, the extent to which a manufacturer benefitted from or encouraged a particular use of its product is far less important than its ability to prevent injuries associated with that use. It is, therefore, unclear why a court would think that a drug manufacturer's role should determine its liability for injuries caused by off-label uses. If a manufacturer can cheaply warn of a significant risk associated with an off-label drug use, and thereby avoid any liability costs associated with the risk, it is hard to see why the manufacturer's duty to do so should depend on the profit it derived from the use or the extent to which it promoted the use.

Perhaps the attraction of looking at the benefit to the manufacturer or the manufacturer's encouragement of an off-label use is that such approaches seem to address directly the manufacturer's culpability. However, this consideration is not persuasive for two reasons.

First, although determinations of liability for failure to warn necessarily rely on reasonableness considerations (since there is no other way to evaluate the "adequacy" of a warning), drug products liability law need not wholly abandon strict products liability principles in favor of a simple negligence system. ${ }^{97}$ In particular, there is no reason why manufacturer fault should be any more relevant to drug products liability than it is to the liability of automobile manufacturers, which are held to a true strict liability standard. Using negligence-type reasonableness considerations to evaluate warnings does not require conditioning liability on manufacturer fault.

Second, even assuming that manufacturer culpability is relevant to drug products liability, one might just as well understand such culpability in terms of failing to prevent an avoidable 
injury-specifically, failing to warn of a known risk-as in terms of encouraging or benefiting from an off-label use without providing adequate warnings. It is not intuitively obvious that a drug manufacturer that fails to warn of a risk that is well known to the manufacturer but not to the prescribing physician is significantly less culpable because it derives little economic benefit from the use in question than it is if it also happens to profit from the use. Although some people might feel greater immediate outrage toward a drug manufacturer that makes a profit under such circumstances, a manufacturer that does not make such a profit is hardly guiltless, and from a social standpoint, both manufacturers should be provided with equally strong incentives to warn of the risk. ${ }^{98}$

\section{Acceptance by the Medical Community}

Another intermediate approach to manufacturer liability for failure to warn of risks associated with off-label drug uses focuses not on the manufacturer's role, but on the attitude of the medical community toward the off-label use in question.

In Upjohn Co. v MacMurdo, the plaintiff's injuries stemmed from the off-label contraceptive use of the drug Depo-Provera. ${ }^{99}$ The court rejected the argument that the manufacturer could not be liable because it had warned physicians that such use of the drug was unapproved, pointing out that "there was medical testimony that in appropriate circumstances a physician may properly prescribe a drug for a purpose other than that for which it has been approved." 100 While the court's reasoning is not entirely clear, it appears to have based its conclusion that drug manufacturers can be liable for injuries caused by off-label uses on the fact that off-label prescriptions are sometimes medically proper. It seems, then, that the MacMurdo court would only find a manufacturer liable for failure to warn of a risk associated with an off-label drug use if the general medical community accepted the use as appropriate therapy. ${ }^{101}$

99 The same argument can be made with respect to promotion of off-label drug uses or other aspects of a drug manufacturer's role. Although a drug manufacturer that promotes a risky off-label drug use may appear to be in some sense more evil than a manufacturer that knowingly stands by while physicians unwittingly write dangerous off-label prescriptions, the latter manufacturer certainly seems to deserve significant moral blame as well.

562 S2d 680, 682 (Fla 1990).

190 Id at 682-83.

101 An alternative interpretation of MacMurdo is that, since a drug's manufacturer 
The appeal of a rule requiring manufacturers to warn of the risks of an off-label drug use only if the use has been accepted by the general medical community is unclear. Such an approach limits manufacturer liability, which is generally desirable, but, like the approaches focusing on the drug manufacturer's role, it does so arbitrarily and gives manufacturers insufficient incentives to warn of the risks of some off-label uses. There is no reason why a drug manufacturer that knows that physicians are treating their patients with an off-label drug therapy should be freed of a duty to warn those physicians of significant risks to their patients just because the larger medical community has not concluded that the off-label use is effective. Courts should focus on reducing the risks to which patients are exposed and on giving manufacturers incentives to reduce those risks through warnings to physicians. To this end, whether a particular off-label drug use is widely accepted among physicians or is listed in pharmaceutical reference works seems irrelevant.

If there is any rationale for limiting manufacturer liability to cases involving generally accepted off-label drug uses, it may be a fear of subjecting manufacturers to liability for the negligence of physicians who prescribe dubious off-label therapies. As argued above, however, there are ways to avoid turning manufacturers into insurers of inept physicians without relieving them of a duty to warn of risks associated with off-label drug uses. ${ }^{102}$

may not know all of the drug's medically proper off-label uses, the manufacturer must warn of risks related to all off-label uses. Since the MacMurdo court found that the drug manufacturer's warning in that case was adequate, id at 683 , the court did not need to clarify precisely when manufacturers are liable for injuries caused by off-label uses.

Another case has suggested, like the reading of MacMurdo proposed in the text, that manufacturers need only warn of risks associated with off-label uses when those uses are accepted by the general medical community. In Rhoto $v$ Ribando, the plaintiff was injured by a diet program that involved five prescription drugs, only one of which was approved for weight control. 504 S2d 1119, 1120, 1124 (La Ct App 1987). The court found that the warnings for two of the drugs, Renese and HGC, were adequate, id at 1124-25, although it appears from the opinion that neither drug's manufacturer warned of the risks in question. The court said that a manufacturer must warn of risks associated with any "normal use" of its product. Id at 1124. In finding that weight loss was not a "normal use" of the drugs, the court relied on the testimony of medical experts that the drugs did not have any "legitimate use" for weight control and that such use of them was a "gross misuse." Id. The manufacturers thus had no duty to warn of risks of the off-label use, not because the use was unapproved by the FDA, but because it was not medically acceptable.

${ }^{102}$ See text accompanying notes 70-71. 
E. Foreseeable Misuse

Two final cases present a more promising approach. In $\mathrm{Med}$ ics Pharmaceutical Corp $v$ Newman, the plaintiff was injured by the off-label use of DES as a miscarriage preventative and sued the supplier, which claimed "that it did not recommend or market its product for that purpose."103 The court held that "[w]hether a manufacturer or distributor of DES should have foreseen it would be used for preventing miscarriages is a question of fact for the jury." ${ }^{104}$ If the jury found that such use of the drug was foreseeable, the court held, the manufacturer could be liable. ${ }^{105}$

A similar case is Richards $v$ Upjohn Co., which involved injuries stemming from use of the drug neomycin sulfate to irrigate a wound following surgery, a use for which the manufacturer had withdrawn its recommendation several years earlier. ${ }^{106}$ Reversing a grant of summary judgment, the court held that there was a genuine issue of fact as to the adequacy of the manufacturer's warnings of the risks associated with this use of the drug, despite the fact that the manufacturer no longer recommended it at the time of the plaintiff's injury. ${ }^{107}$ The physician's apparent negligence in using the drug to irrigate a wound would not, according to the court, protect the manufacturer from liability if such use of the drug was reasonably foreseeable. ${ }^{108}$

According to the Newman and Richards courts, drug manufacturers are liable for failure to warn of risks associated with reasonably foreseeable off-label drug uses. This is the familiar products liability doctrine of foreseeable misuse, according to which manufacturers are liable for injuries caused when their products are misused in a reasonably foreseeable manner. ${ }^{109}$ In the drug products liability context, the doctrine requires manufacturers to warn of the risks associated with all foreseeable uses of their products-including approved uses, foreseeable off-label uses, and foreseeable uses that are obviously inappropriate.

204 Id.

165 Id at $488-89$.

$1 \% 55$ NM 675, 625 P2d 1192, 1194 (NM Ct App 1980).

${ }^{107}$ See id at 1196.

109 Id at 1196-97.

169 See 3 American Law of Products Liability $3 d \S \S 42: 11-42: 14$ at 26-32 (cited in note $63)$. 
Of the positions examined so far, that of Newman and Rich$a r d s$ is the most attractive. It gives manufacturers broad incentives to warn of the risks associated with the most significant offlabel drug uses, but it also limits their potential liability costs, since they need only warn of risks of uses about which, for the most part, they already know. However, even this approach is not ideal, and the weaknesses of the foreseeable misuse rule become apparent when it is compared to the new rule proposed in the following Section.

\section{A PROposed DUTY to WARN OF ALl DEMONSTRATED RisKS}

While the foreseeable misuse approach of Newman and Richards may approximate the ideal distinction between those cases in which manufacturers should be liable for failure to warn of risks of off-label drug uses and those cases in which imposing liability excessively raises manufacturers' costs, a superior distinction can be drawn by addressing the problem directly. A better approach would require drug manufacturers to warn of all demonstrated risks associated with off-label drug uses, but would not hold a manufacturer liable for failure to warn of undemonstrated risks, even those of which it perhaps should have known, although it did not.

Note first that there is no obvious reason for determining the extent of manufacturer liability for injuries caused by off-label drug uses, as the courts have, with reference to some class of offlabel uses-those that accounted for significant sales, those accepted by the general medical community, those that are reasonably foreseeable, and so forth. Why not define liability with reference to risks instead? That is, rather than asking which uses are such that manufacturers should be liable for failure to warn of any associated risk, courts could ask which risks are such that manufacturers should be required to warn of them, and which risks are such that imposing a duty to warn would excessively raise manufacturers' costs.

Once a drug manufacturer knows of a risk-knows not just that some patient was injured, while using a drug, but that a drug can actually cause a specific injury-it is very inexpensive for the manufacturer to warn of the risk. ${ }^{110}$ Accordingly, there

110 The costs of warning go beyond the minimal additional printing costs of adding it to the package insert, since the manufacturer must also lobby the FDA for permission to include the warning. Given the FDA's willingness to approve scientifically supported warnings, however, the overall costs of adding a warning should still be low. See text 
is no reason why the manufacturer should not bear full liability for failure to warn of such a risk, and courts should provide manufacturers with the strongest possible incentives to give such warnings. Liability for failure to do so will not significantly increase manufacturers' costs, since they can inexpensively shield themselves from liability by providing adequate warnings.

Liability threatens to burden drug manufacturers with high costs in cases where plaintiffs allege that manufacturers should have known of risks of which, in fact, they were unaware. Such cases impose high costs on manufacturers for a number of reasons. The uncertainty inherent in determining whether a manufacturer should have known of a risk both encourages litigation and makes it more expensive. Moreover, a duty to warn of all risks of which a manufacturer should know forces manufacturers to investigate carefully all reported injuries that may be related to drug use and to perform costly research to determine exactly which possible risks are real. ${ }^{111}$

These observations suggest a rule subjecting drug manufacturers to liability for failure to warn of risks associated with offlabel drug uses only when manufacturers have actual knowledge of the risks in question. However, the natural concern about such a rule is that it will be underprotective of patients. Manufacturers may have such control over their knowledge that they could, through willful ignorance, immunize themselves from a duty to warn of risks of which they could, if they were more diligent, easily learn and warn. But recall that FDA regulations require manufacturers to monitor all physician reports of adverse drug reactions and to keep abreast of developing scientific knowledge about their drugs. ${ }^{112}$ Since drug manufacturers are already subject to these requirements, it should impose no significant new costs on manufacturers if courts charge them with constructive knowledge of all risks either reported to them by physicians or documented in the scientific literature. ${ }^{113}$

accompanying notes 60,75 .

Lost sales attributable to a new warning are an indirect cost of the warning that the manufacturer must also bear. However, assuming that lost sales are due to physicians appropriately choosing not to prescribe the drug because they better understand its risks, it would obviously be a mistake to attempt to minimize such costs.

11 For a discussion of the difficulties involved in trying to determine whether injuries suffered by patients taking a drug were in fact caused by the drug, see W. Leigh Thompson, Adverse Drug Reactions: Finding Sharp Safety Signals in a Noisy Haystack, 46 Food Drug Cosm L J 487 (1991).

112 See text accompanying notes $45-46$.

${ }^{113}$ As noted above, courts have charged manufacturers with such constructive knowl- 
A drug manufacturer's duty, then, should be to warn of all demonstrated risks of off-label drug uses, whether they are demonstrated by the manufacturer's own research, the research of others, or physicians' experiences using the drug. ${ }^{114}$ The exact content of the duty will depend on what counts, given current scientific knowledge, as a demonstration that a risk exists. In any case, a court should not consider a risk demonstrated if patients using a drug have suffered injuries although it otherwise is unclear what actually caused the injuries, if studies merely suggest a risk, or if one of several conflicting studies purports to show a risk.

A duty to warn of only demonstrated risks effectively requires a manufacturer to warn of all risks that are known to anyone. As such, it cannot be manipulated as a duty that depends solely on the manufacturer's actual knowledge might be. And while the proposed rule gives drug manufacturers strong incentives to warn of risks associated with off-label drug uses, it should not impose excessive costs on manufacturers since they need only warn of risks with a demonstrated causal connection to use of the drugs. Drug manufacturers, though under a strong duty to monitor and warn, would then be saved the expenses entailed by a duty to warn of risks of which they merely should have known. The proposed rule does not force manufacturers to conduct follow-up research or to engage in extensive, complex litigation.

At the margin, of course, there may be instances in which it would be efficient for manufacturers to conduct follow-up research on reports of possible risks, although the proposed rule would release them from a duty to do so. However, this danger should not be overestimated. The rule proposed here only governs liability for injuries stemming from off-label drug uses; manufacturers remain under a duty to warn of all risks of which they should know with respect to approved drug uses. Since many risks of off-label uses are also associated with approved uses,

edge in drug products liability litigation related to approved uses. See text accompanying note 47.

114 But note that this does not mean that manufacturers must actually provide warnings of such risks if they are extremely slight. If the odds of injury are only one in five billion, it may well be the case that the duty to provide an "adequate" warning of the risk does not actually require providing any warning at all. Among the questions to be asked when evaluating any warning's adequacy is whether the relevant risk is great enough to warrant a warning at all. While there is no clear formula for answering this question, there is no reason to think that courts should treat the issue any differently in the context of off-label drug uses than in any other context. 
manufacturers will still have an incentive to conduct a certain amount of follow-up research on reports of injuries associated with off-label drug uses. Moreover, the situations in which followup research on reports of injuries caused by off-label drug uses is really warranted are impossible to discern ahead of time. The only alternative is a blanket rule requiring follow-up research in all circumstances, and the threatened costs of such a rule are simply too great.

There is an inevitable trade-off here. Since it is impossible to craft a rule that perfectly distinguishes, at the outset, the cases in which follow-up research is desirable from those in which it is not, any rule that reduces manufacturers' costs will somewhat arbitrarily weaken their incentives to test and warn. The proposed rule holding manufacturers liable for failure to warn of only demonstrated risks is the best compromise. In particular, it is superior to the foreseeable misuse rule, the most promising approach yet suggested by the courts.

The foreseeable misuse rule is both underinclusive and overinclusive in ways that the demonstrated risk rule is not. It is underinclusive because a known risk of some very serious injury is significant and merits a warning if it is relevant to a number of off-label drug uses, none of which is individually foreseeable, although it is foreseeable that some physicians will prescribe the drug for at least some of the uses exposing certain patients to grave danger. ${ }^{115}$ Under such circumstances, the foreseeable misuse rule would not require a warning, but the demonstrated risk rule would.

The potential overinclusiveness of the foreseeable misuse rule is more significant. Under the foreseeable misuse rule, a drug manufacturer is liable for failure to warn of a poorly understood risk of a foreseeable off-label use if the plaintiff can convince the court that the manufacturer should have known of the risk. But a duty to warn of such risks, of which there may be little good evidence, is precisely what threatens to raise manufacturers' costs excessively. It forces manufacturers to bear the costs of follow-up research on questionable reports of injuries possibly related to off-label drug uses, as well as the costs of

${ }^{115}$ For example, although it might be foreseeable that physicians will inject a drug approved only for injection into muscles in some other manner, it may not be foreseeable that physicians will inject the drug in any particular off-label way-into the spine, into veins, etc. Even though the specific off-label use is not foreseeable, as long as all injections of the drug (other than into muscles) are dangerous, a warning would be appropriate. 
more extensive litigation. An important advantage of the demonstrated risk rule is that it does not impose these costs on manufacturers.

Even considering this overinclusiveness of the foreseeable misuse rule, warning levels under the foreseeable misuse rule might not be significantly higher than under the demonstrated risk rule. Relatively common, foreseeable off-label uses should often be quite well understood by the scientific community. If so, most risks of which a manufacturer could learn will already be documented in the literature. There should be few instances of risks associated with common off-label drug uses of which a manufacturer would warn under the foreseeable misuse rule but not under the demonstrated risk rule.

As for unusual, though foreseeable, off-label uses, manufacturers subject to the foreseeable misuse rule might well choose to absorb the liability rather than conduct expensive research relevant to the drug use of only a small number of patients. In such a case, the additional liability of the foreseeable misuse rule would not produce additional warnings and greater safety. Moreover, if a drug were used in an off-label manner to treat a very unusual condition, it might be impossible to collect reliable data on risks associated with the use due to the small number of patients available to study. There would, then, be few undemonstrated risks of such a use of which one could say the manufacturer should have known.

These considerations suggest that adopting the demonstrated risk rule over the foreseeable misuse rule does not entail settling for a significantly lower level of warning. Where the foreseeable misuse rule is underinclusive, the demonstrated risk rule will produce higher levels of warning. And even where the foreseeable misuse rule is overinclusive, imposing excessive costs on drug manufacturers, it is doubtful that manufacturers would respond by providing significantly more warnings than they would provide under the demonstrated risk rule.

As suggested above, however, litigation costs-which benefit only attorneys and constitute a net drain on social resources-should be dramatically lower under the demonstrated risk rule. Litigation under the foreseeable misuse rule requires answering three vague, open-ended questions: Was the off-label use in question reasonably foreseeable? If so, should the manufacturer have known of the risk in question? And if so, was the manufacturer's warning adequate? Since there are no clear standards for answering any one of these questions, litigating each 
will be uncertain and expensive. Moreover, the uncertainty itself will encourage plaintiffs to sue, since they always have a chance of winning, and the awards in these cases can be enormous. ${ }^{116}$

In contrast, only the third of these open-ended questions arises in litigation under the demonstrated risk rule, and that inquiry into the adequacy of the manufacturer's warning is inevitable in litigation that deals with liability for failure to warn. The only other question a court must answer is whether the risk in question has been demonstrated to exist, that is, whether the manufacturer had actual or constructive knowledge of the risk. This issue should be relatively easy to resolve by reviewing the manufacturer's records and the scientific literature. ${ }^{117}$

\section{CONCLUSION}

The problem underlying products liability for injuries caused by off-label uses of prescription drugs is finding a way to give drug manufacturers strong incentives to provide adequate warnings of significant risks without the imposition of excessive costs on them, which may have serious negative consequences. The demonstrated risk rule represents a better solution to this problem than the rules suggested by the courts that have dealt with this issue. Compared to the foreseeable misuse rule, which is the most promising approach in the case law, the demonstrated risk rule should ensure patient safety approximately as well, while imposing much lower costs on manufacturers and generally reducing the social burden of litigation.

A remaining question is whether the demonstrated risk rule can provide the sort of control over off-label drug use that, according to some commentators, is needed. ${ }^{118}$ The answer is unclear. To the extent that the demonstrated risk rule gives drug

116 For instance, in Proctor v Davis, 1994 Ill App LEXIS 995, *1, the jury originally awarded the plaintiff over $\$ 3$ million in compensatory damages and almost $\$ 125$ million in punitive damages. However, the trial court reduced the punitive damages award to $\$ 35$ million, and the appellate court eventually reversed the judgment against the drug manufacturer altogether. Id.

117 Of course, it may be no simple matter to say whether the literature actually demonstrates the existence of a risk. But the advantages of the demonstrated risk approach over the foreseeable misuse approach remain clear. There is still no need to determine, as one must under the foreseeable misuse rule, what a manufacturer should have known in the sense of determining the information of which the manufacturer should have been aware. The potentially difficult question under the demonstrated risk rule is what conclusions the manufacturer should have drawn from the relevant information; however, this question arises under the foreseeable misuse rule as well.

118 See notes 34-37 and accompanying text. 
manufacturers better incentives to warn physicians appropriately of risks of off-label drug uses, it should be an improvement. However, warnings only protect patients if physicians heed them. Insofar as medical malpractice liability is ineffective at regulating off-label drug use, as commentators have suggested, ${ }^{119}$ drug products liability, which focuses on manufacturer warnings, can only furnish a partial solution to the need for further control over off-label drug use. The demonstrated risk rule shares this limitation of all drug products liability rules. Its real benefits lie in how it draws a principled distinction between the cases in which drug manufacturers should and should not be liable for failure to warn physicians of risks of off-label drug uses, giving manufacturers strong incentives to warn at low cost to society. 